\title{
A new species of Ilybius Erichson, 1832 (Coleoptera: Dytiscidae) from the North Caucasus
}

\author{
Новый вид рода Ilybius Erichson, 1832 (Coleoptera: Dytiscidae) \\ с Северного Кавказа
}

\author{
P.N. Petrov ${ }^{1}$ M.I. Shapovalov ${ }^{2} \&$ H. Fery ${ }^{3}$ \\ П.Н. Петров ${ }^{1}$ М.И. Шаповалов², Х. Фери
}

\footnotetext{
${ }^{1}$ U1. Profsoyuznaya 115-2-451, 117647 Moscow, Russia. E-mail: tinmonument@gmail.com Ул. Профсоюзная 115-2-451, 117647 Москва, Россия.

${ }^{2}$ Laboratory for Bioecological Monitoring of the Invertebrates of the Republic of Adygeya, Adyghe State University, ul. Pervomayskaya 208, Maykop, 385000 Republic of Adygeya, Russia. E-mail: max_bio@rambler.ru

Лаборатория биоэкологического мониторинга беспозвоночных животных Республики Адыгея, Адыгейский государственный университет, ул. Первомайская 208, Майкоп, 385000 Республика Адыгея, Россия.

${ }^{3}$ Räuschstr. 73, 13509 Berlin, Germany. E-mail: hanfry@aol.com
}

KEY WORDS: Coleoptera, Dytiscidae, Ilybius chalconatus-group, new species, Russia, Caucasus.

КЛЮЧЕВЫЕ СЛОВА: Coleoptera, Dytiscidae, группа Ilybius chalconatus, новый вид, Россия, Кавказ.

ABSTRACT. A new species of Dytiscidae, Ilybius adygheanus sp.n., is described from the North Caucasus, Russia. It is assigned to the Ilybius chalconatussubgroup, within the species group of the same name, although it lacks the anterodorsal spiniferous punctures on the first four metatarsomeres, characteristic of most individuals of the species belonging to this subgroup. The members of this species group were before Nilsson [2000] treated in the genus Agabus Leach, 1817. The key to species for males of the chalconatus- and erichsoni-groups in Fery \& Nilsson [1993] is modified in part to include the new species.

РЕЗЮМЕ. Приведено описание нового вида из семейства Dytiscidae, Ilybius adygheanus sp.n., с Ceверного Кавказа (Россия). Новый вид входит в подгруппу I. chalconatus в составе одноименной группы, хотя на антеродорзальной поверхности первых четырёх члеников задних лапок он не имеет щетинконосных точек, характерных для большинства особей представителей этой подгруппы. Виды данной группы до работы Нильссона [Nilsson, 2000] относили к роду Agabus Leach, 1817. Таблица для определения видов групп I. chalconatus и I. erichsoni по самцам [Fery \& Nilsson, 1993] частично видоизменена для включения в нее нового вида.

\section{Introduction}

The genus Ilybius Erichson, 1832, as defined by Nilsson [2000], so far comprised the 67 species already listed in the world catalogue of Dytiscidae by Nilsson [2001] plus Ilybius minakawai Nilsson \& Ribera, 2007. These 68 species are known exclusively from territories within the Holarctic zoogeographical region; 65 are distributed in the Palaearctic, two in the Nearctic, and one in both.

The chalconatus- and erichsoni-groups were revised by Fery \& Nilsson [1993; then still placed in the genus Agabus Leach, 1817]. It was suggested in that revision and later shown by Nilsson [2000] that these two species groups should be included in the genus Ilybius because they share the character states that are synapomorphic with the other species of that genus. A chromosomal analysis of several species from both groups [Aradottir \& Angus, 2004] supported the transfer of these groups to the genus Ilybius.

Recently some specimens from the Russian Caucasus became available which belong to the Ilybius chalconatus-group, but proved not to be identifiable with the key to species given in Fery \& Nilsson [1993]. These specimens belong to a new species, which is described below as Ilybius adygheanus sp.n.

\section{Material and methods}

The male and female genitalia have been studied and figured in wet condition. The terminology denoting the orientation of the genitalia and hind legs follows Miller $\&$ Nilsson [2003]: the (usually) convex surface of the penis is termed ventral (formerly it was considered dorsal) and the (usually) concave surface dorsal (formerly considered ventral); surfaces of the hind leg parts (femur, tibia, tarsomeres) observed in ventral view, which intuitively might be called "ventral", are here termed "anterior"; the margins of these hind leg parts which if the hind legs are stretched and orientated perpendicular to the body axis - intuitively might be called 
"anterior" are here termed "dorsal". Coordinates of the localities are given in decimal notation.

The following abbreviations are used for depositories mentioned in the text:

CHF - coll. H. Fery, Berlin, Germany, property of

Naturhistorisches Museum Wien, Vienna, Austria

CPP - coll. P.N. Petrov, Moscow, Russia

CMS - coll. M.I. Shapovalov, Maykop, Republic of Adygeya, Russia

ZIN - Zoological Institute of the Russian Academy of Sciences, St. Petersburg, Russia

ZMUM - Zoological Museum of Moscow State University, Moscow, Russia

\section{Taxonomy}

The chalconatus-group is well defined, and included 19 hitherto known species; 17 of these are known to occur only in the Palaearctic and two only in the Nearctic [Fery \& Nilsson 1993]. The chalconatus-subgroup included so far the following six species: Ilybius bedeli (Zaitzev, 1908), Ilybius chalconatus (Panzer, 1796*), Ilybius dettneri (Fery, 1986), Ilybius gagates (Aubé, 1838), Ilybius horzgargantae (Burmeister, 1983) and Ilybius larsoni (Fery \& Nilsson, 1993).

The chalconatus-group, within the genus Ilybius, can be diagnosed by the following set of characters (after Fery \& Nilsson [1993], modified in accordance with Nilsson's [2000] placement of this species-group in the genus Ilybius): (1) pronotum with lateral margin more or less evenly curved, without sinuation near anterior angle; (2) male anterior protarsal claw without basal excavation; (3) metatarsomeres 1-4 with distal margin more or less straight, without ventral lobe; (4) first male metatarsomere without anteroventral bead; and (5) metatarsal claws subequal in size and shape. The chalconatus-subgroup shows the following additional features: (6) penis symmetrical, dorsal groove not visible in lateral view; (7) paramere with distal 1/4 relatively broad and with rather long setae and (8) with thin proximal setae and thicker adhesive setae apically.

\section{Ilybius adygheanus Petrov, Shapovalov \& Fery sp.n. Figs 1-9}

TYPE MATERIAL: Holotype: $\sigma^{7}$ in ZIN labelled: "Respublika Adygeya [Republic of Adygeya], pos. [posyolok = settlement] Krasnooktyabrskiy 58, 19.V.2004. leg. Shapovalov M.I.", "Ilybius ? n.sp., chalconatus-grp, det AN Nilsson-06", and our label "Holotype, Ilybius adygheanus sp.n., Petrov, Shapovalov \& Fery, 2010" [red, printed] (holotype completely preserved, except the left antenna, which lacks the last nine antennomeres). Paratypes: $3 \sigma^{\top} \sigma^{\top} \& 2$ + with the same data label as holotype (but mostly without Nilsson's identification label): $1 \sigma^{7} \& 1$ in ZIN (9 with the same identification label as the holotype), $\sigma^{\gamma}$ in ZMUM, $\sigma^{\gamma}$ in CMS, + in CHF; 1 ऽ labelled "Respublika Adygeya, Maykopskiy $r-n$ [rayon $=$ district], okr. p. [okrestnosti posyolka $=$ environs of village] Mirnyy 135 6.VI.2006. leg. Shapovalov M.I." in CPP; 1 " labelled "[Krasnodar Territory,] Goryacheklyuchevskoy [= Goryachy Klyuch], okr. Lysoy gory [env.

* Indicated as 1797 in the world catalogue [Nilsson, 2001], subsequently corrected by Nilsson [2004].
Mount Lysaya], 23.VI.2005, leg. Shapovalov M.” in CHF (all labels in Russian, here transcribed, with explanations of abbreviations and translations in square brackets). All paratypes with our red printed labels: "Paratype, Ilybius adygheanus sp.n., Petrov, Shapovalov \& Fery, 2010".

Note: The holotype and the paratypes were originally pinned, but later glued by us on cards.

TYPE LOCALITY: Republic of Adygeya, Maykop district, environs of Krasnooktyabrskiy settlement: 44.58N 40.08E.

DIAGNOSIS. The new species shows all characters given above for the chalconatus-group and chalconatus-subgroup members, and, additionally, has a penis with apex sharply pointed in lateral view, distal portion thin and apex rounded in ventral view. A strongly pointed penis in lateral view is a rare character among members of the chalconatus-group, found only in two other species: I. pseudoneglectus (Franciscolo, 1972) of the montanus-subgroup and I. hulae (Wewalka, 1984) of the hulae-subgroup.

DESCRIPTION. Body elongate oval, dark reddish brown to black, appendages reddish brown.

Head mostly dark reddish brown to black; clypeus and two spots on vertex reddish brown. Pronotum mostly black; anterior angles, lateral rim and rather broad poorly delimited area beside rim reddish brown to dark brown; anterior and posterior margins narrowly lighter brownish, slightly transparent. Elytra black, with sides diffusely dark brown.

Clypeus with anterior bead widely interrupted medially. Boundary between frons and clypeus marked with two small sublateral grooves, frons with strong puncture behind each of these grooves. Pronotum with hind angles almost right angles; maximum width of pronotum at hind angles; sides weakly curved, converging anteriorly; lateral rim distinct,
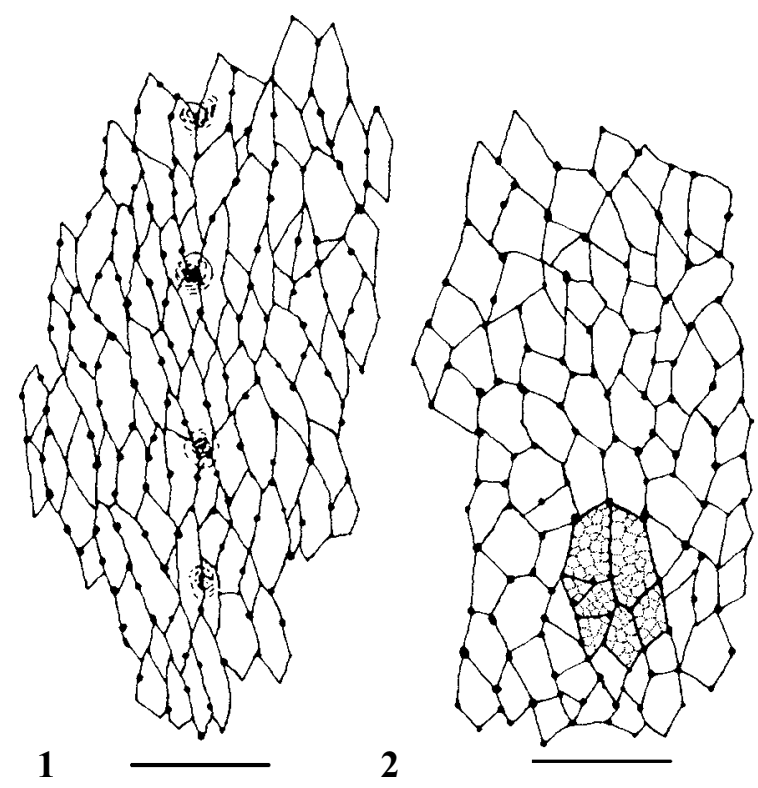

Figs 1-2. Elytral surface of Ilybius adygheanus sp.n.: 1 middle of anterior half of elytron; $2-$ middle of posterior half of elytron. Microreticulation shown only in a few meshes. Scale bar $0.1 \mathrm{~mm}$.

Рис. 1-2. Поверхность надкрылий Ilybius adygheanus sp.n.: 1 - в передней половине надкрылья (в ее середине); 2 - в задней половине надкрылья (в ее середине). Мелкая сетчатость показана только на нескольких ячейках крупной сеточки. Масштабный отрезок - 0,1 мм. 
obsolete near front angles. Sides of elytra less curved in anterior two thirds, stronger so behind. Lateral margin of body in dorsal view continuously curved, without indentation at hind angles of pronotum and shoulders of elytra Maximum width of body at middle of total length, almost immediately behind first third of elytra.

Dorsal surface entirely reticulated; meshes relatively small, more or less polygonal, of unequal size and variable shape. Setae very sparse and almost imperceptible, confined to larger punctures on pronotum and elytra. Head with micropunctures at most intersections of reticulation lines and some additional micropunctures along these lines. Pronotum with reticulation similar to that on head, but micropunctures less distinct; row of punctures behind anterior margin sparser medially, but not interrupted, punctures becoming distinctly coarser towards sides; row of punctures before posterior margin broadly interrupted medially, punctures coarser and more irregular. Elytra with meshes similar to those on head and pronotum, but rather elongate on disc, except in posterior third; meshes of reticulations with fine microreticulation near apex, smooth elsewhere; lines of reticulation with numerous micropunctures along them and occasionally at intersections; near apex, however, most intersections with micropunctures, but lines without such punctures (Figs 1-2). Each elytron with four not very prominent longitudinal series of punctures, two on disc, third more laterally, fourth near lateral margin; punctures in these series relative small, smaller than meshes, irregularly arranged, those near sides rather sparse; on posterior third of elytra punctures becoming progressively weaker and more irregularly positioned.

Ventral surface mostly black, only gena, proepisternum, prothoracic epipleuron, elytral epipleuron anteriorly and posterior margins of abdominal ventrites 3-5 dark reddish brown; posterior margin of abdominal ventrite 6 (apical) broadly reddish brown. Antenna reddish brown, apical antennomere not darkened distally; mouth appendages reddish brown;

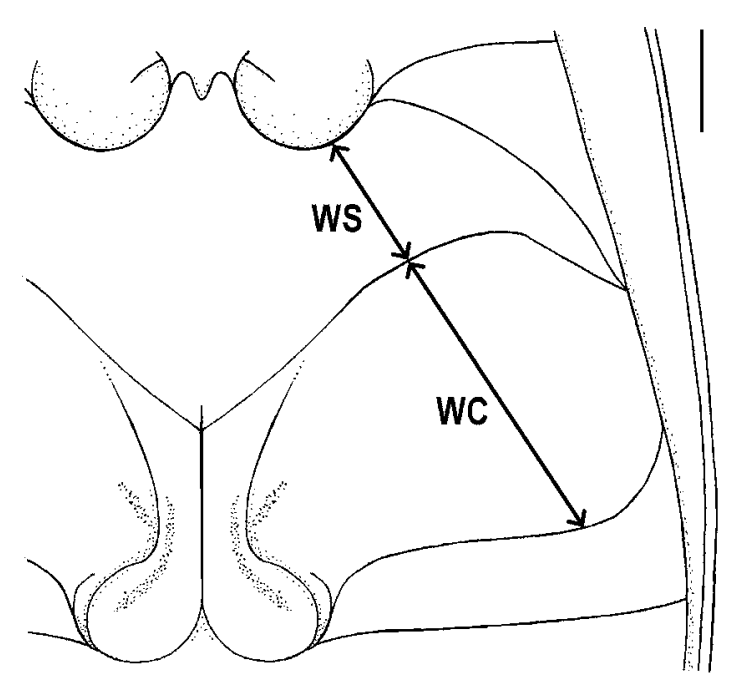

Fig. 3. Metasternum and metacoxae of Ilybius adygheanus sp.n., with the measurements of WC (width of metacoxal plates) and WS (width of metasternum at narrowest point of lateral lobe) shown. Scale bar $-0.5 \mathrm{~mm}$.

Рис. 3. Заднегрудь и задний тазик Ilybius adygheanus sp.n.; показаны параметры WC (ширина заднего тазика) and WS (ширина заднегруди в наиболее узком участке ее боковой лопасти). Масштабный отрезок - 0,5 мм.
Legs mostly reddish brown, but pro- and mesocoxa, all trochanters and much of femora proximally darker (most of metafemur very dark, almost black, except lighter apex) and metacoxae black, except very dark brown metacoxal process.

Reticulation on ventral surface largely consisting of rather large irregular elongate meshes; oriented more or less parallel to body axis on metacoxal plates, abdominal ventrites 1 and 2 and sides of abdominal ventrite 3 , but more or less perpendicular to body axis on abdominal ventrites 4-6 and broad medial portion of abdominal ventrite 3 ; meshes on sides of abdominal ventrites mostly incomplete, changed to rather long somewhat irregular subparallel scratches. Areas with meshes or long scratches on abdominal ventrites and metacoxal plates interspersed with micropunctures, especially numerous on metacoxal plates.

Metacoxal plates anteriorly and laterally with some weak irregular rugae oriented mostly perpendicular to body axis. Metasternum medially rather smooth, with only traces of reticulation, covered with rather dense fine micropunctures; more laterally with stronger and more irregular punctures and stronger reticulation; lateral lobes ("metasternal wings") of metasternum with strong irregular punctures and strong scratches deformed into some small, rather irregular grooves.

Prosternal process glabrous, posteriorly pointed; behind procoxae almost tectiform in cross section, with lateral bead distinct, becoming obsolete at apex. Metasternal wings of medium width (see Fig. 3 and Measurements). Metacoxal lines diverging anteriad, not reaching hind margin of metasternum. Hind margin of apical abdominal ventrite evenly rounded.

Anterior surface of metatibia near dorsal margin with two and near posterior margin with one series of more or less strongly impressed longitudinal punctures, each of them with a strong spine; with some additional smaller punctures proximally; dorsal margin of metatibia with another similar series of punctures. Metatarsomeres without anterodorsal spines; metatarsomeres 1-4 with external apical angles obliquely cut, not lobed.

Antennae with antennomere 4 shorter than 3 and 5, antennomeres 5 to 10 of subequal length, antennomere 11 slightly shorter than antennomere 10 .

Males: Apical half of last abdominal ventrite with distinct longitudinal rugae, except more or less smooth middle. Male pro- and mesotarsomeres 1-3 weakly dilated, with short adhesive setae; protarsal claws subequal in size and shape, anterior protarsal claw without basal excavation present in erichsoni-group members (Fig. 4); mesotarsal claws also subequal in size and shape. Metatarsomeres without anteroventral bead. Metatarsomere 5 simple, without ventral furrow; anterior metatarsal claw thinner, slightly shorter and apically slightly more curved than posterior claw.

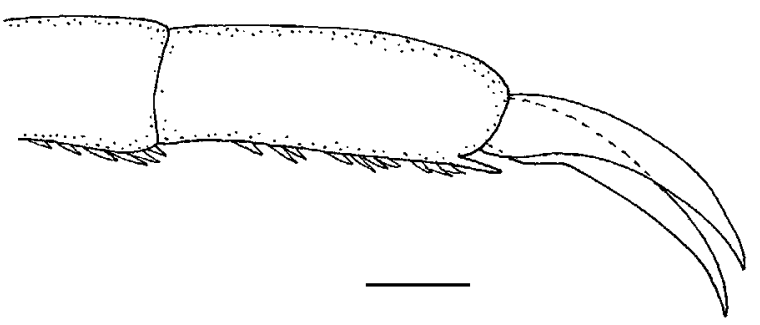

Fig. 4. Male right protarsomere 5 of Ilybius adygheanus sp.n. with claws in posterior view. Scale bar $-0.1 \mathrm{~mm}$.

Рис. 4. Пятый членик правой передней лапки Ilybius adygheanus sp.n. с коготками, вид сзади. Масштабный отрезок-0,1 мм. 

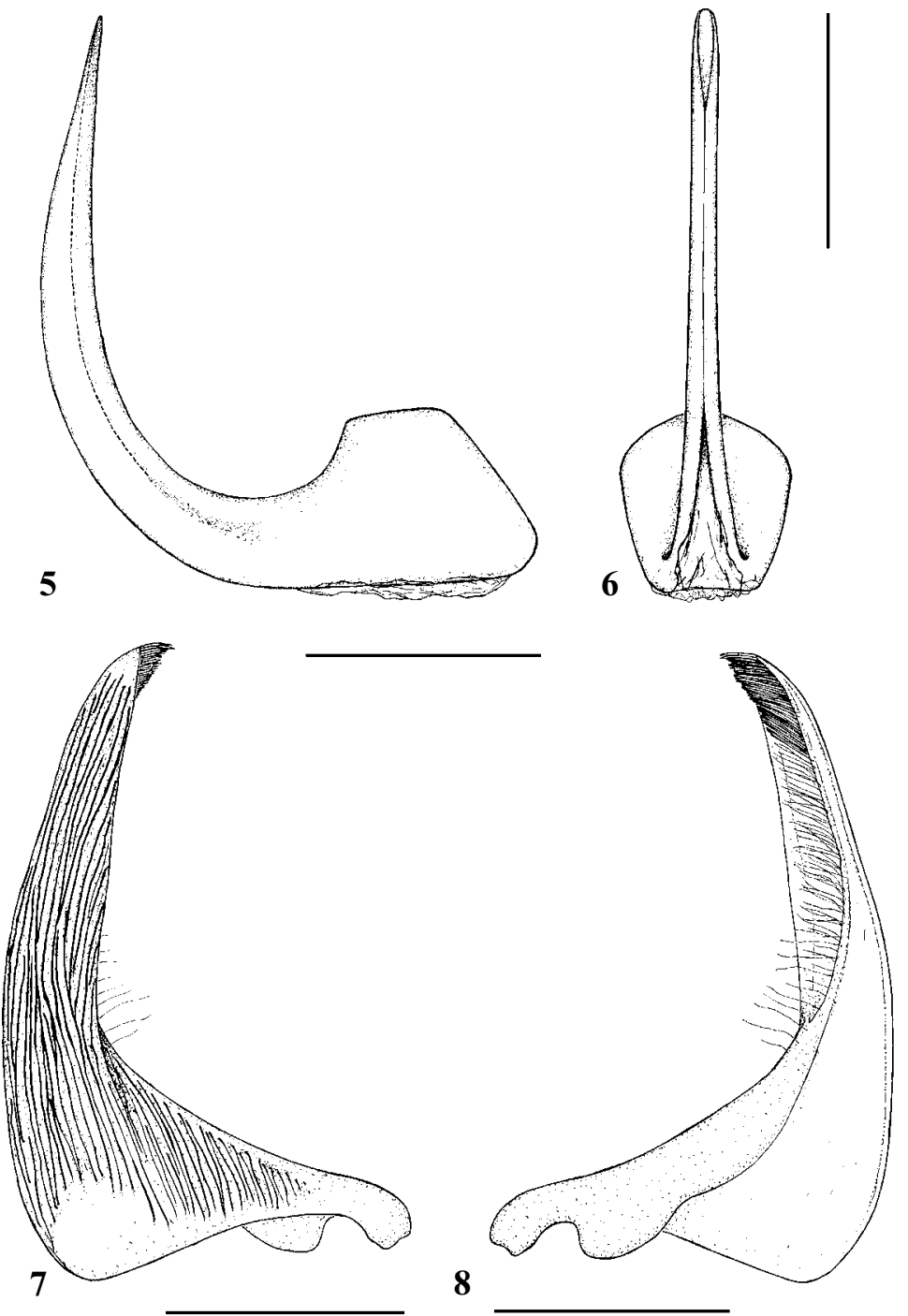

Figs 5-8. Male genitalia of Ilybius adygheanus sp.n.: 5 - penis in lateral view; 6 - penis in ventral view; 7 - right paramere in external view; 8 - right paramere in internal view. Scale bar $-0.5 \mathrm{~mm}$.

Рис. 5-8. Гениталии самца Ilybius adygheanus sp.n.: 5 - пенис, вид сбоку; 6 - пенис, вид снизу; 7 - правая парамера, снаружи; 8 - правая парамера, изнутри. Масштабный отрезок - 0,5 мм.

Penis symmetrical, ventral groove more or less straight and not visible in lateral view; apex of penis strongly pointed in lateral view (Fig. 5); in ventral view very thin over almost entire length, apex rounded (Fig. 6). Paramere with distal quarter relatively broad (maximum width in distal quarter subequal to width medially), with strong longitudinal striae on external surface over entire length except base and apex (Fig. 7); apically with short but dense fringe of relatively short rigid adhesive setae; proximally with fine soft setae, however, often not visible in external view; proximal setae stemming from carina on inner side of paramere, from subapical area to near base, not perceptible in external view if not oriented adequately (Fig. 8).

Females: Similar to males, but microreticulation near elytral apex more extended and more strongly impressed. Longitudinal rugae on last abdominal ventrite very weak; metatarsal claws almost equal in size and shape, but anterior claw with apex slightly more curved than posterior one. Gonocoxae and tergite 9 as in Fig. 9.

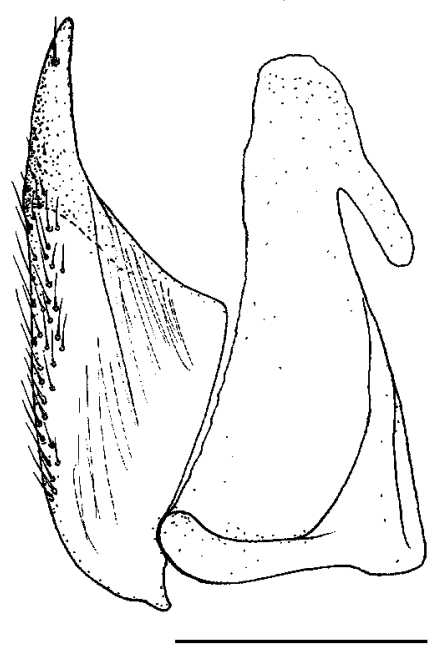

Fig. 9. Female genitalia of Ilybius adygheanus sp.n.: gonocoxa and abdominal tergite 9 in lateral view. Scale bar -0.5 $\mathrm{mm}$.

Рис. 9. Гениталии самки Ilybius adygheanus sp.n.: гонококса и девятый тергит брюшка, вид сбоку. Масштабный отрезок - 0,5 мм.
Note: Females of this species are hard to distinguish from those of I. chalconatus, the geographical range of which includes the range of the new species, and, thus, in particular single females of these two species from the Caucasus should be treated as "not exactly identifiable".

Measurements: Total length $8.2-8.9 \mathrm{~mm}$ (holotype: $8.9 \mathrm{~mm}$ ), maximum width $4.5-5.1 \mathrm{~mm}$ (holotype: $4.9 \mathrm{~mm}$ ). WC/WS 2.2-2.6 (holotype: 2.3) (see Fig. 3).

VARIATION. The known variability is restricted to the total body length and width, shape of metasternal wing (and value of WC/WS), and extent of lighter areas on ventral and sides of dorsal surface, probably depending on the degree of maturity and sometimes reflecting post-mortem changes.

DISTRIBUTION. Known so far only from the North Caucasus, Russia: from the Republic of Adygeya and from one locality (Goryachy Klyuch) in the Krasnodar Territory, which completely surrounds this republic.

BIONOMICS. Adults of this species were collected in late spring and early summer (from mid-May to late June), in 
a seasonal pool filled with rainwater at the edge of a hornbeam forest with earthy bottom and submerged leaf litter, and in a ditch $0.5 \mathrm{~m}$ deep, between a highway and a field, with silty bottom and plant debris. Otherwise nothing is known.

ETYMOLOGY. The specific epithet is an adjective, latinized form of the English adjective Adyghe (pertaining to Adygeya or its people).

TAXONOMIC POSITION. The new species belongs to the chalconatus-group as defined in the Introduction. Fery \& Nilsson [1993] recognized four subgroups inside that group: hulae-, neglectus-, montanus-, and chalconatus-subgroups. The new species belongs to the chalconatus-subgroup, though it lacks the anterodorsal spiniferous punctures on metatarsomeres $1-4$, characteristic of most individuals of the species belonging to this subgroup.

MODIFIEd PART OF THE Key tO MALES OF the ILYBIUS CHALCONATUS-GROUP

The key to species given below is a modified portion of the key to males of the chalconatus-group provided by Fery \& Nilsson [1993]. See the same work for illustrations of some characters of the species mentioned. The numbers with asterisk refer to figures in Fery \& Nilsson [1993].

17. Paramere with strong transverse striae (Figs $48 \mathrm{a}^{*}-49 \mathrm{a}^{*}$ ); apical and proximal setal fringes fused. Body length 9.3$10.7 \mathrm{~mm}$ (Nearctic species) .. 18

- Paramere with longitudinal striae strong or weak; apical and proximal setal fringes distinctly separated (Figs 41a*, $44 a^{*}-47 a^{*}$, Fig. 7) (Palearctic species). ventral view (Figs 49b*, c*). Body length 9.3-10.7 mm. I. larsoni (Fery \& Nilsson, 1993)

- Penis narrow in lateral view, with apex sharply pointed in ventral view (Figs 48b*, c*). Body length $9.8 \mathrm{~mm}$. ......

I. gagates (Aubé, 1838)

19. Paramere rather broad in distal third and with strong more or less longitudinal striae over entire surface (Fig. 7). Apical setae rather short, proximal setae present, scarcely perceptible in external view, but obvious in internal view (Fig. 8). Penis with apex sharply pointed in lateral view (Fig. 5), in ventral view distal portion thin and apex rounded (Fig. 6) (Endemic of the Caucasus). I. adygheanus sp.n.

- Paramere strongly narrowed in distal third, striae rather weak, more transverse, in particular near base (Figs 41a*, $\left.44 a^{*}-47 a^{*}\right)$. Apical setae longer. Penis with apex distinct- ly rounded in lateral view, rounded or pointed in ventral view. ................................................................. 19a

19a. Penis short, with apex more broadly rounded in ventral view; body length in most specimens less than $9.4 \mathrm{~mm}$. Piew; body length in most specimens less than 9.4 mm. 20

- Penis long, with apex more pointed in ventral view; body length in most specimens more than $9.4 \mathrm{~mm}$.

21

20. Paramere with striation more developed and basal setae long (Figs 41a*, 44a*). Sternum 7 [= ventrite 6] in most specimens rugose in distal half (Fig. 36*). Body length 7.6-9.5 mm. ..................... chalconatus (Panzer, 1796)

ACKNOWLEDGEMENTS. We thank A.N. Nilsson (Umeå, Sweden), for his help with recognizing this species as new. We also thank A.R. Bibin (Maykop, Adygeya, Russia), N.B. Nikitsky (Moscow, Russia) and A.A. Prokin (Voronezh, Russia), for their help with the transfer of specimens, and R.B. Angus (London, UK) for checking and correcting the English of our manuscript. The work of M.I. Shapovalov was supported by the Russian Foundation for Basic Research and the administration of the Krasnodar Terriiàry, project \# 09-04-96554-r_yug_a, and the Federal Agency for Education, project \# 2996.

\section{References}

Aradottir G.I. \& Angus R.B. 2004. A chromosomal analysis of some water beetle species recently transferred from Agabus Leach to Ilybius Erichson, with particular reference to the variation in chromosome number shown by I. montanus Stephens (Coleoptera: Dytiscidae) // Hereditas. Vol.140. P. 185-192.

Fery H. \& Nilsson A.N. 1993. A revision of the Agabus chalconatus- and erichsoni-groups (Coleoptera: Dytiscidae), with a proposed phylogeny // Entomologica Scandinavica. Vol.24. No.1. P.79-108.

Miller K.B. \& Nilsson A.N. 2003. Homology and terminology: Communicating information about rotated structures in water beetles // Latissimus. No.17. P.1-4.

Nilsson A.N. 2000. A new view on the generic classification of the Agabus-group of genera of the Agabini, aimed at solving the problem with a paraphyletic Agabus (Coleoptera: Dytiscidae) // Koleopterologische Rundschau. Vol.70. P.17-36.

Nilsson A.N. 2001. World catalogue of insects. Vol.3. Dytiscidae (Coleoptera). Stenstrup: Apollo Books. 395 pp.

Nilsson A.N. 2003. Dytiscidae // Löbl I. \& Smetana A. (eds). Catalogue of Palaearctic Coleoptera. Vol.1. Stenstrup: Apollo Books. P.35-78.

Nilsson A.N. 2004. World catalogue of Dytiscidae - corrections and additions, 2 (Coleoptera: Dytiscidae) // Koleopterologische Rundschau. Vol.74. P.157-174. 